\title{
Rust, Leandro Duarte Colunas de São Pedro: a política papal na Idade Média central
}

\author{
Maria Filomena Pinto da Costa Coelho*
}

São Paulo: Annablume, 2011. 569p.

Leandro Rust is a historian who, like very few others, has accepted the challenge of Walter Benjamin: brushing history against the grain. A difficult task, particularly if the chosen object of study belongs to the category of major historiographical monuments, as is the case of the Papacy. In political terms, his story creates a referential model which transcends religious structures, and even gives significance to the source of inspiration and experience of the secular state in the West. The history of the papacy in the Middle Ages, especially between the eleventh and thirteenth centuries, has been understood as fundamental for understanding the origins of the process of the strengthening/centralization of the state. More specifically, historiography has even established an initial time for this, which has become known as the Gregorian Reform.

The historical interpretation which has supported over the past two centuries the Western political and institutional matrix has been criticized, and a number of historiographical works have already been transformed into indispensable references from different perspectives (Anglo-Saxon, Italian, French and Iberian historiography - although the latter only to a lesser extent). However, this phenomenon is confined largely to the political realities of secular power. There is a profusion of research groups concerned with revisiting the documents/monuments which founded the history of power and institutions and to encouraging intense debate about the explanatory tradition which, especially from the nineteenth century onwards, has presented power in a single form and with a unique source, from the top to the bottom and usually acting against society to control it and master it from outside. The results of these discussions and research are clear and open new possibilities for the history of the state in the West. In addition, it is striking that the Church, as an

\footnotetext{
* Programa de Pós-graduação em História (PPGHIS) and Departamento de História, Universidade de Brasília (UnB). Instituto de Ciências Humanas, Campus Universitário Darcy Ribeiro - ICC Norte. 70910-900 Brasília - DF - Brasil. filo-coelho@hotmail.com
} 
object of study, has been left out of this renewal, since often, as a state institution it was the only one to truly understand and experience the essence of that political model. The explanations for this absence/presence are varied, and Leandro Rust's book is very helpful for reflecting on this as it unveils the construction of the image of an institution that faced huge political challenges in the nineteenth and early twentieth centuries, and which placed itself as the guardian and precursor of the best political values of the West, whose roots date back to the Gregorian Reform.

Leandro Rust does not fall into the puerile trap of wanting to present a new interpretation to discredit the old historiography. His proposal has another intention, totally in tune with what the historian's craft should be, which is to explain why at certain times in history the past is explained in a certain form. His thought runs in several directions and timelines. The documents studied from the epoch are, of course, of interest to him, but so is the historiography that gave meaning to these records. Colunas de São Pedro thereby reaffirms the maxim that history is made from documents, but also from historiography.

Colunas de São Pedro is divided into two parts which, according to the title, support the ecclesia institution: territoriality of power and power over time. Although these two supporting columns are apparently more familiar to those versed in the historiography of the medieval Church, the fact is that there can be found in them the great challenge that the author proposes: perceiving these pillars differently. This is not to diminish their strength, but to show that the material they are made from is something else.

It was, therefore, necessary to start with a thorough analysis of the historiography - undoubtedly one of the highlights of the book. The way historians of the Church and of polities have solidified explanations and concepts to the point of naturalizing them requires from researchers a refined and permanent work of criticism. Among the many examples that arise throughout the book, we can highlight the problem of the concept of 'institution,' which Leandro Rust had to address early in his work. While, on the one hand, the concept could have acquired an explicitly anachronistic form, on the other hand, defining content was difficult, since almost everything fits into the experience of the research. Throughout the book the author allows glimpses of the paths chosen - the method - to disentangle the concept from the sources. A fine exercise in history that allows us to understand the papal institution in the Middle Ages as the 'decision-making power of the popes' using records that are already well known: synods and councils. The cornerstone, however, rests on how the 
historian looks at these documents/monuments. Not as 'ready-made' universal institutions, but with the curiosity of one who wants to understand how a text came to be written and what it meant at the time it was produced. The politics which pulsates in institutions.

One of the columns of the historiographical tradition of the Church is positive law. In the words of Rust, a "widely circulated image of those holding pontifical power acting under fierce obedience to textual rules and canonical collections... the Roman See as a social space in the medieval era, differentiated, bureaucratic and dominated by the logic of jurists" (p.27). When considering the historiography itself as an integral part of the object of study, it was possible to arrive at an understanding that the image cited was deeply linked to another historiographical problem: the idea of Reform. An idea which is materialized and 'repeated' in history and in the contemporary era acquires the inescapable force of $a$ 'political project.' In relation to this the documents chosen by the author - also used by this same historiography - allow another possible interpretation. Legal texts when interpreted in their context, reveal themselves not as the result of the will of an autocratic pope-king, but as a result of intense negotiations and complex pacts that integrate the voice of the pontiff in the various groups of power in Christendom, throughout all Europe. A territoriality of power which is far from focusing exclusively on Rome, which acquired regionalized connotations, and which can only be configured through the logic of personal networks, in which the papacy tried to actively participate. Similarly, the column of time is not made of eternity, but finitude; the papacy used the time of men to voice its decisions, but, in the same spirit of malleability and judicial personhood, time is also mobile and changeable. It is thus possible, when necessary and appropriate, to invent permanences and continuities, to legitimate causes and to restructure the voice of authority.

In Leandro Rust's opinion, reforming practices are not the explanatory key to understanding the politics of the papacy between 1040 and 1210. By proposing that the rise of the papacy be understood as a political phenomenon - and not cultural, social, or economic -, there is an important shift: it was not 'reform' that gave historical meaning to this ascension. Therefore, stopping talking about the Gregorian Reform - as proposed by some authors - and adopting instead expressions such as Papal Reform or Ecclesiastical Reform is not a solution to the historiographical problem. The leading role of 'reform' refers directly to the reformist discourse of Catholicism in the late nineteenth century and during the Second Vatican Council. The careful analysis that Rust makes of the documentation shows that despite the moral question and 
spirituality being important, it was not these aspects which outlined the course of politics.

Leandro Rust's conclusion is historiographically blunt:

The eleventh century marks the political rise of the Roman See, not as the precursor of a modern type of centralization and bureaucracy, but as a Church forced to overcome exceptional weaknesses. Between 1040 and 1130, the exercise of papal power followed the same logic outlined by the experiences of time which little remind us of the 'construction of a modern state.' It counted on a regular institutional arrangement, steadily perpetuated by generations, it was interpersonal, established as a mode of integrated decision making with wide social coverage and prolonged permanence. This stable and collective disposition of decision making constituted what we mean by papal institutionalization... The pontifical institutions with which we are faced were social actions endowed with a particular meaning, they had, in fact, specific purposes that were not alien to seigniorial society, but neither were they 'creations' of the papacy... The pontifical institutions, therefore, cannot be defined at the starting point of historical research. They cannot be previously classified and categorized so that the researcher can only then investigate what the documentation has to say about them.

Chapter 6, on the 1130 Schism, deserves a special comment. Undoubtedly, it is in this chapter where the reader can see most clearly the decentralization of papal politics and its poly-nuclear nature, i.e., how it was supported by several seigniorial columns, to such an extent that the political center of the Schism was Gaul, and not Rome. Long before the fourteenth century, and Avignon, the papal policy already excelled in displacement and mobility - not centralization and settling down.

Finally, we cannot fail to highlight the exhaustive work with sources. Leandro Rust faced the challenge of carefully rereading documentation well known for unveiling other meanings. The result of this effort indicates, notwithstanding his youth, great knowledge and erudition, allowing him to rebuild intricate political networks and unveil the plots of judicial-institutional discourse.

Review received on 18 July 2012. Approved on 26 October 2012. 